arguments in the problem with detachment and clarity, so that a rational decision appeared possible once more. As a chairman, he was superb.

In recent years, he was much in demand as an expert in industrial psychology, who could make his subject appeal to audiences at all levels. He made outstanding contributions to the conferences held over a number of years by the National Coal Board at Oxford, and to the apprentices' conferences held since 1950 by the Industrial Welfare Society at Keble College.

As a person, he was happily extroverted and completely unselfconscious. He had a great affection for people, and took a deep and genuine interest in the academic progress, personal problems and later careers of hundreds of students who passed through his hands. He was sympathetic without being sentimental, he helped them to tackle their problems objectively and realistically, and men and women all over the world have reason to be grateful for his patience, his kindness and his wisdom.

Elizabeth D. Fraser

\section{Prof. W. E. Tröger}

Prof. Walter Ehrenreich Tröger, the distinguished German mineralogist and petrologist, died in Freiburg im Breisgau on January 13.

Born in Dresden on January 19, 1901, he studied mining and mineralogy in the Mining Academy of Freiberg in Saxony, an institution famous in the history of geology. From this Academy he graduated in 1924 with a degree in mining engineering. Another four years of study in the Dresden Technical High School culminated in a degree of Doctor of Engineering in 1928. In 1937 he became extra. ordinary professor of mineralogy at the University of Dresden, and from 1948 until 1952 he held a similar post at the Mining Academy of Clausthal, in 1952 extraordinary professor at the Technical High School in Darmstadt, and finally, in 1956, professor of mineralogy, petrology and ore deposits in the University of Freiburg im Breisgau.

Both the Darmstadt and the Freiburg mineralogical institutes had been greatly damaged during the War, and a great part of Tröger's time was spent in supervising the rebuilding of these institutions and in restoring and rearranging the collections, a difficult and laborious task which he carried out with great success. This work naturally cut into his time for his own research. This covered a wide field of mineralogy, petrology and ore deposits, first in his native Saxony and then in Odenwald and Harz. He described a number of minerals and igneous rocks and he gave the name 'bebedourite' to a variety of biotite-jacupirangite from Brazil. A characteristic feature of Tröger's writing was his terseness and precision, which are most clearly manifest in his two excellent and useful books.

One of these books is a tabular and diagrammatic representation of data relating to rock-forming minerals, the first edition of which was published in 1952, and the second in 1956. In this book the data are presented almost entirely in tabular form supported by numerous figures of crystals and various diagrams and projections.

The other book, much used by petrologists throughout the world, is entitled: Spezielle Petrographie der Eruptivgesteine: Ein Nomenklatur-Kompendium. It was published by the German Mineralogical Society in 1935 and the same Society published a supplement entitled Eruptivgesteinsnamen (1 Nachtrag) in 1938 . The original book contains names and data relating to 777 species of igneous rocks and a list of 345 group-names, synonyms, 'stillborn' and obsolete rock-names. The supplement adds 140 new rock names, producing a total of 917 names of igneous rock species. Each of these species is given with concise information comprising the following items: author, reference, type locality, mineral composition, chemical composition, Niggli values, CIPW symbol, colour ratio, synonyms and varieties. The rocks are classified according to the two main variables-silica percentage and alkali percentage. It is most unfortunate that copies of this book are no longer obtainable, for the entire stock was destroyed during the War and Tröger himself was using the only remaining single copy left in the departmental library of his Institute. During the last years of his life Tröger was busy amplifying and revising this book for a projected new edition, but his premature death has left it unfinished.

Tröger was an excellent organizer, a perfect field geologist and an excellent teacher. He possessed a most charming personality and acted as a kind host to the numerous geologists of many nationalities who came to Freiburg im Breisgau in order to examine the two 'star' geological localities in its neighbourhood: Kaiserstuhl and Schwarzwald.

'Tröger's death, at the early age of 62 , is a loss not only to science but also to the many scientists who, having met him, could appreciate him as a personality apart from his writings.

S. I. TOMKEIEFF

\section{Dr. Lyman J. Briggs}

Dr. Lyman J. Briggs, director emeritus of the National Bureau of Standards, U.S. Department of Commerce and chairman emeritus of the Committee for Research and Exploration at the National Geographic Society, died on March 25. He was eighty-eight years old.

Dr. Briggs began his career in the Federal Service in 1895 as a physicist in the U.S. Department of Agriculture. During this period, he made historic contributions in the application of physics to agriculture, and organized what is now known as the Bureau of Plant Industry.

With the outbreak of the First World War, Dr. Briggs was assigned by executive order to work on war problems at the National Bureau of Standards. At the conclusion of the War, he stayed on and soon became chief of the Mechanics and Sound Division. In association with Paul R. Heyl, he invented the earth inductor compass, which later guided Lindbergh on his first trans-Atlantie flight. For this device, they received the Magellan Medal of the A.merican Philosophical Society in 1922.

His interests in aerodynamics resulted in pioneer measurements of flow around aeroplane wings at very high speeds up to and exceeding the speed of sound. Much of this work was done in association with Hugh L. Dryden, now deputy administrator of the National Aeronautics and Space Administration.

In July 1932, Dr. Briggs was appointed acting director of the National Bureau of Standards. Although the Bureau's operating funds were almost immediately cut in half in an economy measure, he was able to guide the laboratory through the depression period while preserving nearly two-thirds of the career employees in a working organization.

With the advent of the Second World War, Dr. Briggs directed that almost 90 per cent of the staff be assigned to work on problems of national defence. This work later resulted in such developments as the radio proximity fuse, improved optical glass, and the Bat guided missile.

In 1939, Dr. Briggs was asked by President Roosevelt to head and organize a secret investigation of the possibility of utilizing energy of atomic fission of uranium. Two years later this committee became section $S-I$ of the Office of Scientific Research and Development with Dr. Briggs as chairman and Profs. H. C. Urey, E. O. Lawrence, J. B. Conant, E. O. Murphee and A. H. Compton making up the executive committee. Much of the early work on the methods of purification of uranium, establishment of specific properties, and separation of isotopes of uranium was done at the Bureau under Dr. Briggs's direction with the assistance of distinguished guest workers.

Dr. Briggs officially retired from the Bureau in October 1945 although he continued to pursue his research interests 
at the Bureau until very recently. During this period, he published important papers on such diverse subjects as negative pressures in liquid and the dynamics of a curving baseball. He also served as chairman of the research committee of the National Geographic Society.

Dr. Briggs was born near Battle Creek, Michigan, and received a bachelor degree from Michigan State College at the age of nineteen. He was awarded a master of science degree in physics from the University of Michigan and a Ph.D. from Johns Hopkins University. For many years, Dr. Briggs was a member of the National Advisory Committee for Aeronautics (the predecessor of National Aeronautics and Space Administration) and vice-chairman in 1942. He was a director of the American Standards Association and a member of the American Physical Society, Washington Academy of Sciences, Philosophical Society of Washington, American Philosophical Society, and the U.S. National Academy of Sciences.

\section{NEWS and VIEWS}

\section{Central Electricity Generating Board:} Dr. T. E. Allibone, C.B.E., F.R.S.

Dr. T. E. Allibone has been appointed chief scientist of the Central Electricity Generating Board, as from October 1. Dr. Allibone was educated in the University of Sheffield and Gonville and Caius College, Cambridge. During 1926-30 he was the 1851 Exhibition Senior Student, Cavendish Laboratory, Cambridge. He joined the Metropolitan-Vickers Electrical Co., Manchester, where he was in charge of the High Voltage Laboratory until 1946. From 1944 until 1945 he was also a member of the British Mission on Atomic Energy, Berkeley, California, and Oakridge, Tennessee. Until recently, he was director of the Research Laboratory of Associated Electrical Industries, Ltd., at Aldermaston Court, Berkshire, and is a director of A.E.I. (Woolwich), Ltd.

\section{Chemistry at St. Andrews :}

Prof. J. I. G. Cadogan

DR. J. I. G. CADOGAN, at present lecturer in chemistry at King's College, London, has been appointed to the Purdie chair of chemistry in St. Salvator's College, St. Andrews, in succession to the late Prof. J. Read (see Nature, 198, 336; 1963) from October 1, 1963. Dr. Cadogan, who is thirty-three, obtained first class honours in chemistry at King's College, London, in 1951, and obtained a Ph.D. degree at the same College in 1954. Between 1954 and 1956, Dr. Cadogan held junior and senior Civil Service Commission Research Fellowships at the Chemical Defence Experimental Establishment, Porton, Wiltshire. Since 1956, Dr. Cadogan has been lecturer in chemistry at King's College, London. In 1959 he was Meldola medallist of the Royal Institute of Chemistry and the Society of Maccabeans. In 1961 he was appointed to the War Office Advisory Council on Scientific Research and Technical Development and was also elected to the fellowship of the Royal Institute of Chemistry.

\section{Veterinary Biology at Massey University College :}

DR. D. A. Titchen, at present a university lecturer in veterinary physiology at the Physiological Laboratory, Cambridge, has been appointed to the new chair of veterinary biology at the Massey University College, Palmerston North, New Zealand. After qualifying in veterinary science at Sydney, Dr. Titchen went to Emmanuel College, Cambridge, in 1948, to read for the Part 2 Course in Physiology, and then proceeded to a Ph.D. in 1954. In the same year he was elected to a research fellowship of his College, and in 1958 to an official fellowship. Dr. Titchen's research has been primarily concerned with the elucidation of the causes of the movements of the complex stomach of the ruminant. His early work on decerebrate preparations largely defined the various afferent stimuli which arise in the stomach and lead to reflex excitation or inhibition of the movements of the different compartments. Latterly he has been able to demonstrate by a series of ingenious exporiments the sequence of contractions in the conscious animal in much greater detail than has hitherto been possible. His work has always characteristically shown an ingenious and clear approach and he has always been careful to show its relation to classical physiology. Dr. Titchen, with his experience in teaching physiology to all types of natural scientists at different levels, is well qualified to oceupy this new chair and to start a course in which a fresh and interesting approach is to be made to the study of pre-clinical subjects by the veterinary student.

\section{U.S. Federal Funds for Scjence}

THE eleventh report in the annual Federal Funds for Science series covers the fiscal years 1961,1962 and 1963 (Pp. ix +161 . Washington, D.C. Government Printing Office, 1963. 1 dollar). It reflects an unprecedented increase in Government funds for science and technology, which at 14,400 million dollars for research and development and 12,300 million dollars for plant for that purpose in 1963 was expected to triple the outlay by the Government during the five years of the Second World War. The major increase in 1963, 368 million dollars, is for the Department of Defence. Besides a further 24 million dollars for the Department of Commerce, chiefly for research and development plant facilities, there were sig. nificant increases in research and development funds for the Atomic Energy Commission and the Department of Health, Education and Welfare. The total increase on 1962 is 3,500 million dollars. Four agencies account for 95 per cent of the total Federal estimate for research and development in 1963. About two-thirds of the national funds for research and development came from the Federal Government in 1960-61, when in terms of funds industry was responsible for 75 per cent of research and development in the United States: Federal agencies contributed 15 per cent for intra-mural work and 10 per cent for work by colleges and universities and non-profit institutions. In $1959-60$ some 70 per cent of research and development funds went for development, about 20 per cent for applied research and 9 per cent for basic research. Almost 60 per cent of funds for basic research in 1960-61 were from the Federal Government, industry providing about 25 per cent. Academic institutions were responsible for about 46 per cent of the basic research effort in 1960-61, industry for 31 per cent and Federal institutions for 15 per cent. Of the 1963 estimates for research and development, 65 per cent is for industry, 12 per cent for colleges and universities, 19 per cent for Federal laboratories, facilities and administration, and 4 per cent for non-profit institutions, etc.

\section{U.S. Center for Educational Apparatus}

Prof. F. E. Christensen, of St. Olaf College in Northfield, Minnesota, has been appointed head of the new Center for Educational Apparatus in Physics, which will begin operations early this summer. The Center is a joint project of the American Association of Physics Teachers and the American Institute of Physics and is supported by a grant from the National Science Foundation. It 